\title{
URANOVÝ PRU゚MYSL A RALSKO
}

T. K a fk a : Uranium industry and Ralsko. - Geografie - Sborník ČGS, 103, 3, pp. 253 - 260 (1998). - The former Ralsko military training area is situated in close proximity to the region where uranium is mined. The paper deals with the history of uranium mining and with geological conditions of the territory and characterizes the methods of extraction used - deep mining of uranium ore and chemical extraction by in-situ leaching. Attention is paid to the present organization structure of the uranium industry and to the work of the state firm DIAMO with regard to the elimination of impacts of uranium ore extraction and processing.

KEY WORDS: uranium ore - deep mining - chemical extraction - elimination of impacts of mining.

\section{Úvod}

Uranový průmysl má v České republice dlouholetou tradici. Jako instituce vznikl v r. 1945 na základě smlouvy o průzkumu a těžbě ložisek radioaktivních surovin mezi tehdejší Československou republikou a SSSR. Postupně se rozvíjel v komplexní průmyslové odvětví, zabezpečující kromě průzkumu a těžby ložisek uranové rudy a jejího zpracování další činnosti, jako laboratorní a technologický výzkum, chemickou výrobu, projekční a stavební činnost a další. Do konce 80 . let odpovídala produkce uranového koncentrátu z těžby plánovanému hospodářskému systému se stejnoměrnými ročními objemy bez vlivu výkyvů poptávky a nabídky na světovém trhu s uranem. V souladu s vyhlášením útlumového programu v r. 1989 došlo nejprve k razantnímu omezení produkce a následně $\mathrm{k}$ postupné likvidaci jednotlivých důlních závodů a restrukturalizaci organizace. Ve druhé polovině 90 . let je uranový koncentrát produkován již pouze ze dvou ložisek. Z ložiska Rožná na jižní Moravě, kde je ruda dobývána klasickým hornickým způsobem, a z ložiska Stráž pod Ralskem na Ceskolipsku, na kterém byla aplikována metoda chemického loužení uranu kyselinou sírovou in-situ. Hlavním předmětem činnosti s. p. DIAMO se stala likvidace těžebních a úpravárenských kapacit a sanace těžbou a zpracováním uranové rudy vyvolaného ovlivnění životního prostředí.

Během více jak 50 leté historie si uranový průmysl vytvořil rozsáhlé „knowhow" v oblasti metodiky vyhledávání, průzkumu a těžby uranových ložisek, technologie zpracování uranové rudy, báňských technologií, geologie a hydrogeologie, technologie podzemního loužení in-situ, matematického modelování technologických, hydrochemických a hydrogeologických procesů, likvidace a ekologické sanace dopadů těžby a úpravy uranové rudy do životního prostředí.

Státní podnik DIAMO je jedinou organizací v České republice, zabývající se těžbou a úpravou uranové rudy. Současná podoba státního podniku DIAMO 


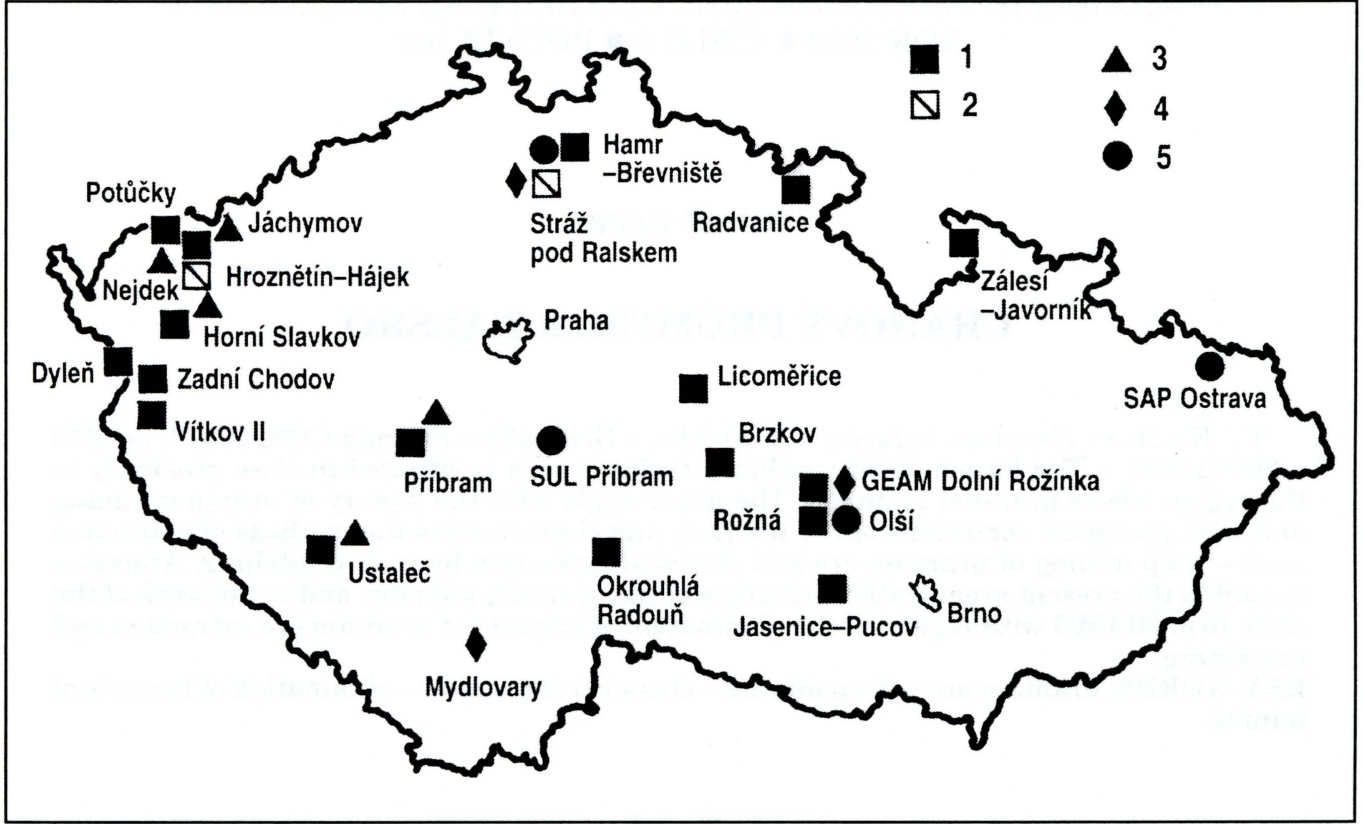

Obr. 1 - Státní podnik DIAMO Stráž pod Ralskem - těžební a úpravárenské lokality a sídla odštěpných závodů. 1 - hlubinná těžba, 2 - chemická těžba, 3 - radiometrická úprava, 4 - chemická úpravna, 5 - odštěpný závod. Stráž pod Ralskem, Rožná = současní producenti Uranu.

vznikla v r.1992 jako nástupnická organizace bývalého koncernu Československý uranový průmysl (ČSUP). Stoprocentním vlastníkem s. p. DIAMO je stát, ř́íícím orgánem Ministerstvo průmyslu a obchodu ČR.

Současná organizační struktura s. p. DIAMO odpovídá charakteru činnosti podniku a rozložení jeho aktivit na území České republiky (viz obr. 1). DIAMO, s. p., Stráž pod Ralskem je členěn na jednotlivé odštěpné závody, kterých je celkem 9. Vlastní těžbou a úpravou uranové rudy a produkcí uranového koncentrátu, se v současnosti zabývají pouze o. z. GEAM Dolní Rožínka a o. z. CHT Stráž pod Ralskem. Další dva významné odštěpné závody jsou o. z. SUL Př́ibram, zabývající se správou a likvidací historických lokalit jako jsou Příbram, Jáchymovsko, Horní Slavkov, Okrouhlá Radouň, atd., a o. z. TÚU Stráž pod Ralskem, v jehož kompetenci je likvidace hlubinné těžby a úpravny v oblasti Hamru na Jezeře Stráže pod Ralskem na Českolipsku. Z hlediska historického významu stojí za zmínku areál chemické úpravny rudy v Mydlovarech v jižních Čechách, jehož likvidace a sanace je zajištována o. z. MAPE Mydlovary. Mimo rámec uranové činnosti stojí o. z. SAP Ostrava, účelově založený v r.1997 pro realizaci sanace ropných lagun Ostramo.

Česká republika je významnou uranovou provincií s řadou ložisek žilného a pískovcového typu. Celkem bylo na území České republiky prozkoumáno 194 ložisek a rudních výskyto̊, z nichž 74 bylo těženo. Bylo vỳhloubeno celkem 550 šachet, 324 štol a 16 povrchových lomù. Od roku 1945 bylo střídavě v činnosti 8 úpravárenských závodů. 


\section{Ložiska uranu v pískovcích severočeské křídové pánve na Českolipsku}

V roce 1963 byly leteckým magnetometrickým průzkumem v okolí Hamru na Jezeře, ležícím na okraji severočeské křídové pánve při úpatí Ještědského hřbetu, zjištěny výrazné anomálie, spojené s do té doby nezjištěným rozsáhlým uranovým zrudněním na bázi svrchokřídového sedimentárního komplexu. Díky tomuto objevu se oblast Hamru na Jezeře s borovými lesy, jezery a pískovcovými skalními městy, která měla do té doby zemědělský a hlavně rekreační charakter, stala oblastí s rozsáhlou těžební činností. V oblasti se rychle rozvinuly vrtné průzkumné práce. Ve srovnání s do té doby těženými ložisky v Jáchymově, Příbrami a jinde, byl zde objeven zcela jiný typ uranového ložiska. Horizontální zrudnění uvnitř svrchnokřídového souvrství, tvořeného dvěma silně zvodnělými pískovcovými souvrstvími, vzájemně izolovanými souvrstvím prachovců, od samého počátku nastolilo otázku způsobu dobývání. Vodu ze spodní cenomanské zvodně, obsahující radioaktivní látky, bylo nutno k umožnění dobývacích prací z prostoru ložiska odčerpat. Svrchní turonská zvodeň je významným zdrojem pitné vody nadregionálního charakteru. Při vedení dobývacích prací bylo tedy nutné zabránit komunikaci mezi těmito dvěma vodonosnými horizonty a znehodnocení turonské zvodně. Rešení problému stanovení vhodného zpưsobu těžební metody se proto ubíralo od počátku dvěma cestami - otevřít ložisko klasickým hornickým způsobem jámami, nebo aplikovat metodu podzemního loužení pomocí vrtů z povrchu. Celkem bylo v oblasti prozkoumáno a výpočtem zásob stanoveno 8 ložisek, z nichž 3 ložiska - Hamr, Břevniště a Stráž - byla těžena. Celková produkce uranu z této ložiskové aglomerace dosáhla 25000 t. Poloha strážského bloku v rámci Ceské republiky je patrná z obrázku 2, obrázek 3 pak znázorňuje lokalizaci jednotlivých ložisek v oblasti strážského bloku.

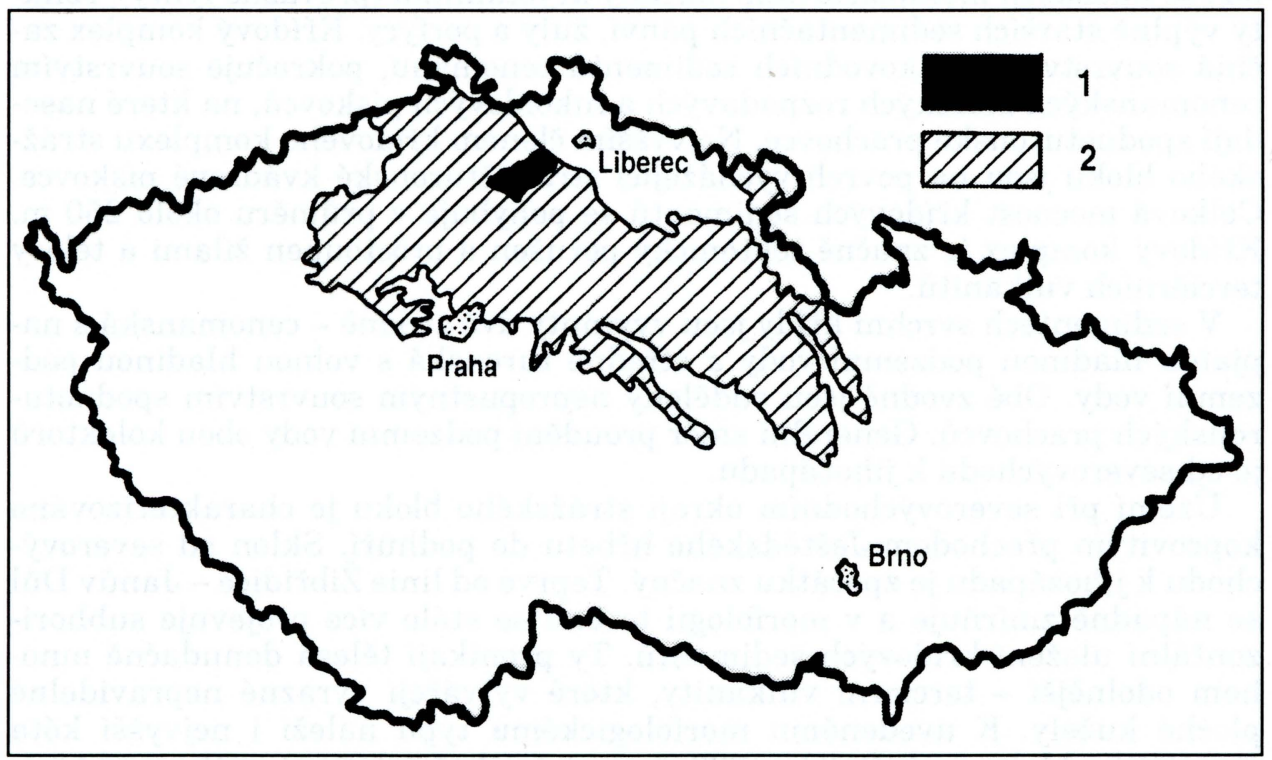

Obr. 2 - Poloha strážského bloku v rámci České republiky. 1 - strážský blok, 2 - Česká kř́ídová pánev. 


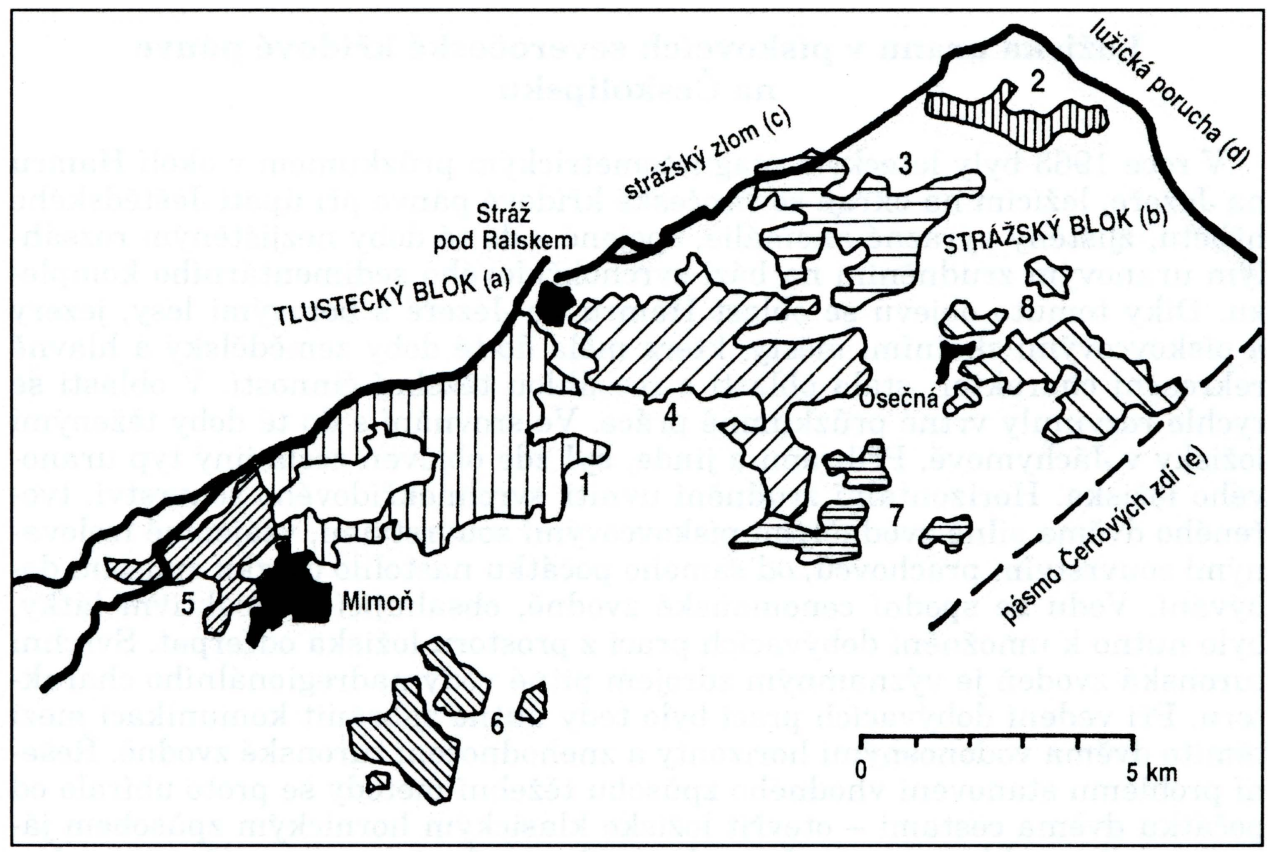

Obr. 3 - Ložiska uranových rud v oblasti strážského bloku. 1 - ložisko Stráž, 2 - ložisko Křížany, 3 - ložisko Břevniště, 4 - ložisko Hamr, 5 - ložisko Mimoň, 6 - ložisko Hvězdov, 7 - ložisko Holičky, 8 - ložisko Osečná - Kotel.

Z geologického pohledu se jedná o ložiska, ležící na bázi svrchnokřídového sedimentárního komplexu strukturní jednotky strážského bloku, v jehož podloží se nacházejí metamorfované horniny krystalinika (převážně fylity), relikty výplně starších sedimentačních pánví, žuly a porfyry. Kř́ídový komplex začíná souvrstvím sladkovodních sedimentů cenomanu, pokračuje souvrstvím cenomanských mořských rozpadavých a fukoidových pískovců, na které nasedají spodnoturonské prachovce. Nejvyšším členem křídového komplexu strážského bloku jsou na povrch vycházející středněturonské kvádrové pískovce. Celková mocnost kř́idových sedimentů se pohybuje v průměru okolo $250 \mathrm{~m}$. Křídový komplex je značně tektonicky porušen a prostoupen žílami a tělesy terciérních vulkanitů.

V sedimentech svrchní kř́ídy jsou vyvinuty dvě zvodně - cenomanská s napjatou hladinou podzemní vody a středně turonská s volnou hladinou podzemní vody. Obě zvodně jsou odděleny nepropustným souvrstvím spodnoturonských prachovců. Generelní směr proudění podzemní vody obou kolektorů je od severovýchodu k jihozápadu.

Území při severovýchodním okraji strážského bloku je charakterizováno kopcovitým přechodem Ještědského hřbetu do podhưř́í. Sklon od severovýchodu k jihozápadu je zpočátku značný. Teprve od linie Žibřidice - Janův Důl se nápadně zmírňuje a v morfologii terénu se stále více projevuje subhorizontální uložení křídových sedimentů. Ty pronikají tělesa denudačně mnohem odolnější - tercierní vulkanity, které vytvářejí výrazné nepravidelné ploché kužely. $\mathrm{K}$ uvedenému morfologickému typu náleží i nejvyšší kóta strážského bloku vrch Ralsko (696 m n. m.), jehož relativní výška nad terénem je asi $400 \mathrm{~m}$. 
$\mathrm{V}$ těsné blízkosti ložisek uranové rudy se nachází několik významných územních a krajinných celků. Jedná se o chráněné přírodní celky rašeliniště Cerného rybníka, vrchy Stohánek, Děvín, Ostrý a Schachtstein, Malý a Velký Jelení vrch, Ralsko a Vranovské skály. Vrchy, tvořené z reliéfu křídových sedimentů vypreparovaným vulkanitem, jsou chráněnými lokalitami s výskytem cenných rostlinných i živočišných druhů (především vzácných druhů hmyzu). Velmi významným územním celkem je vlastní Hamerské jezero, území navržené $\mathrm{k}$ vyhlášení př́rodní rezervace, obklopené borovými lesy, $\mathrm{v}$ minulosti tradiční rekreační centrum s několika tábory a středisky. V oblasti se také nachází ložisko peloidů, které zásobuje blízké Lázně Kundratice léčivým bahnem. Nezalesněné části území jsou intenzivně využívány zemědělskou výrobou, vodní plochy jsou využívány pro rybářství. Jižně od řeky Ploučnice mezi Stráží pod Ralskem a Osečnou byla v minulosti vybudována rekreační oblast a v těsné blízkosti Osečné se nacházejí jmenované Lázně Kundratice.

$\mathrm{Na}$ jihovýchodě od oblasti vyluhovacích polí chemické těžby uranu se rozkládá bývalý vojenský újezd Ralsko, kde po dlouhá léta hospodařila Sovětská armáda. Přestože lze jen těžko spekulovat o vzájemném ovlivnění obou rozdílně využívaných oblastí, spojuje tyto oblasti statut za doby komunistické vlády př́sně střežených a utajovaných územních celků. Obě území jsou propojena účelovými komunikacemi, a to především v blízkosti vsi Svébořice, která leží př́mo na společné hranici. Na sever a severozápad od Svébořic se rozkládají vyluhovací pole VP16, VP15, VP14B, VP14A a VP9B, na jih a jihovýchod se táhnou lesy vojenského újezdu s pěchotní a tankovou střelnicí. $\mathrm{Na}$ území vojenského prostoru zasahuje chráněné ložiskové území Ploužnice, vztahující se k ložisku radioaktivních surovin Hvězdov.

Oblast vyluhovacích polí ložiska Stráž pod Ralskem leží v sousedství ochranného pásma vodního zdroje Mimoň. Vzhledem k významu tohoto zdroje jsou na jeho ochranu před zasažením technologickými roztoky kladny vysoké požadavky.

\section{Hlubinná těžba uranové rudy na ložiscích Hamr a Břevniště}

V letech 1965 až 1975 byl v Hamru na Jezeře vybudován rozsáhlý důlní závod, pro jehož potřeby začala být $\mathrm{v}$ nedaleké Stráži pod Ralskem budována chemická úpravna rudy. Provoz chemické úpravny byl zahájen v roce 1975. Hlubinná těžba se od poloviny 70 . let extenzivně rozvíjela nejenom na ložisku Hamr (Důl Hamr I), ale také na ložisku Břevniště, ležícím od Hamru přibližně $4 \mathrm{~km}$ severovýchodně. Od roku 1973 byl budován Důl Křrižany I, jehož první dobývky byly otevřeny koncem roku 1983. S ohledem na zvrat $\mathrm{v}$ potřebách uranové rudy však došlo v roce $1990 \mathrm{k}$ zahájení likvidace tohoto důlního závodu. V roce 1980 se začalo s hloubením jam Dolu Hamr II - Lužice. V červnu 1988, bylo od další hornické činnosti na připravovaném dole $\mathrm{z}$ ekonomických důvodů upuštěno a následně byla zahájena likvidace areálu.

Současně $\mathrm{s}$ budováním důlního závodu byly provedeny také první pokusy $\mathrm{s}$ podzemním loužením uranu pomocí vrtů z povrchu. První průmyslové množství uranu z pokusného vyluhovacího pole VP3 bylo získáno v listopadu 1967. Tento vyluhovací pokus i ty, které následovaly, byly neštastně realizovány na ložisku Hamr v těsné blízkosti dolu. Chemická těžba loužením uranu in-situ byla od počátku 70. let rozsáhle aplikována na sousedním ložisku Stráž, ležícím přibližně $3 \mathrm{~km}$ jihozápadním směrem. 
Toto bezprostřední sousedství - koexistence - hlubinné a chemické těžby na dvou ložiscích stejného typu a ve stejném litostratigrafickém prostředí vyvolalo mnoho technologických problémů. Nejzásadnějším z nich byla nutnost zajistit pro chemickou těžbu v oblasti ložiska Stráž potřebnou úroveň hladiny cenomanských vod. To bylo zajištěno vytvořením umělého hydraulického rozvodí - bariéry - mezi oblastí dolu hlubinné těžby a oblastí vyluhovacích polí. Barieru tvoří linie vtlačných hydraulických vrtů, které ze severovýchodu a východu obepínají po obvodu část plochy vyluhovacích polí ložiska Stráž. Celková délka bariéry je cca $6 \mathrm{~km}$. Mezi obcemi Svébořice a Mimoň na jihovýchodním okraji vyluhovacích polí byla později vybudována menší hydraulická bariéra s cílem zabránit úniku technologických roztoků. Systém hydraulických bariér tvoří svým způsobem technické unikum v oblasti.

\section{Chemická těžba loužením in-situ na ložisku Stráž}

Chemické loužení uranu in-situ, tedy přímo v horninovém prostředí, představuje za prríznivých geologických a technologických podmínek ekonomicky i ekologicky přijatelnou těžební metodu. Principem této dobývací technologie je, zjednodušeně popsáno, vtláčení loužícího činidla (v případě ložiska Stráž zředěná kyselina sírová) do rudonosné horninové vrstvy pomocí systému vrtů $\mathrm{z}$ povrchu. Roztok prochází horninovým prostředím kde dochází $\mathrm{k}$ loužení uranu a nabohacený užitkovou složkou je čerpán druhým vrtným systémem na povrch, kde je chemicky dále upravován. Po získání uranu je roztok regenerován a vtlačen zpět do podzemí. Bohužel v Hamersko-Strážské oblasti došlo $\mathrm{k}$ rozvoji jak hlubinné, tak chemické těžby v těsné blízkosti, což výrazně zkomplikovalo provoz obou závodů. Navíc se chemická těžba v 80 . letech velmi rychle rozšiřrovala. Tempo nárůstu plochy vyluhovacích polí a objemu vtláčených roztoků neodpovídalo úrovni znalostí o možném negativním dopadu této metody nao životní prostředí. Riziko kontaminace turonské zvodně, zdroje pitné vody, bylo s postupem znalostí o geologické stavbě více a více zřejmé.

$\mathrm{Z}$ podstaty metody chemické těžby je zřejmé, že vlivem této technologie dochází především $\mathrm{k}$ ovlivnění horninového prostředí a podzemních vod, vyvolanému vtláčením loužících roztoků a dalších chemikálií. V menší míře potom dochází $\mathrm{k}$ ovlivnění ekosystémů a to především změnou rázu krajiny (odlesnění plochy vyluhovacích polí, výstavba přístupových komunikací a areálů povrchových technologií), změnou půdních poměrů, změnou chemismu půd a změnou vodního režimu. Tato ovlivnění bývají menšího rozsahu než je tomu u těžby prováděné klasickým hlubinným či povrchovým způsobem.

$\mathrm{K}$ nejrozsáhlejšímu ovlivnění podzemních vod došlo $\mathrm{v}$ rudonosném cenomanském souvrství. Vtláčením technologických roztoků bylo postupně kontaminováno 186 mil. $\mathrm{m}^{3}$ vod. Oblast kontaminace cenomanských vod se rozkládá na ploše $24 \mathrm{~km}^{2}$. Hlavními kontaminanty jsou sírany, amonné ionty, ionty hliníku a radionuklidy, především uran a thorium. Celkové množství rozpuštěných látek v cenomanském kolektoru je cca 4,8 mil. t.

Kontaminace vod turonského kolektoru je nechtěným sekundárním projevem chemické těžby. Docházelo $\mathrm{k}$ ní postupně $\mathrm{v}$ průběhu těžby a to především průsakem povrchových úniků loužících roztoků, porušením výstroje vrtů a přestupem kontaminace $\mathrm{z}$ cenomanské zvodně $\mathrm{v}$ místech přírodního či umělého propojení turonského a cenomanského kolektoru. Celkově bylo kontaminováno $80 \mathrm{mil} . \mathrm{m}^{3}$ turonských vod na ploše $7,5 \mathrm{~km}^{2}$. Hlavními kontaminanty jsou sírany a amonné ionty. Celkově se v turonském horizontu nachází 
25 - 30 tis. tun rozpuštěných látek. Kontaminace turonského kolektoru nemá plošný charakter, nýbrž tvoři ,čočkovité“ mraky, což odpovídá způsobu jejího vzniku. Kontaminace turonských vod je závažným problémem vzhledem ke skutečnosti, že se oblast chemické těžby nachází ve vyhlášeném území CHOTAV severočeská křída.

Chemická těžba uranu v oblasti strážského bloku byla zahájena ve 2 . polovině 60 . let. $\mathrm{Za} 30$ let dobývání bylo do horninového prostředí vtlačeno cca 4100000 tun $\mathrm{H}_{2} \mathrm{SO}_{4}, 320000$ tun $\mathrm{HNO}_{3}, 113000$ tun $\mathrm{NH}_{3}, 26000$ tun $\mathrm{HF}$ a 1000 tun $\mathrm{HCl}$. Pro účely těžby bylo realizováno cca 1500 geologicko průzkumných vrtů, 600 hydrogeologických vrtů a 7700 technologických vrtů. Naprostá většina vrtů prochází nepropustným prachovcovým souvrstvím spodního turonu, které odděluje cenomanský a středně turonský kolektor. Toto umělé narušení izolačního charakteru prachovců spodního turonu představuje pro turonskou zvodeň - vzhledem $k$ hydrogeologickému režimu - významné riziko.

\section{Likvidace následků těžby a zpracování uranové rudy v Hamersko-Strážské oblasti}

Cílem realizace nápravných opatření je komplexní likvidace důlních děl a povrchových objektů v celé oblasti, vyjma povrchových objektů a zařízení vhodných pro další využití, sanace a rekultivace odvalů a odkališt a jejich následné začlenění do krajiny. Cílem likvidačních prací a sanačních opatření při zahlazování následků chemické těžby uranu je uvést horninové prostředí do stavu, který vyloučí znehodnocení pitných vod severočeské křídy, následně provést likvidaci vrtů a nevyužitelných zařízení, která byla pro těžbu využívána, a konečně provést rekultivaci povrchu vyluhovacích polí v souladu s plány budoucího využití území.

Likvidace hlubinné těžby je $\mathrm{v}$ časové ose rozčleněna do třech základních etap. Postupně dojde $\mathrm{k}$ založení vydobytých prostor v podzemí, likvidaci důlních děl ústících na povrch a povrchových areálů důlních závodů, likvidace vrtů a rekultivace některých odvalů. Jámy a vrty musí být zlikvidovány takovým způsobem, aby bylo zamezeno komunikaci mezi turonskou a cenomanskou zvodní. Dále bude likvidován areál chemické úpravny, hlušina $\mathrm{z}$ odvalů bude využita při sanaci odkalište. Poslední v pořadí bude likvidace a sanace odkališt chemické úpravny, která budou po technické sanaci biologicky rekultivována. $\mathrm{V}$ exponovaných místech oblasti bude prováděn monitoring.

Problematika dalšího pokračování chemické těžby uranu ve Strážské oblasti byla řešena vládou ČSFR či ČR v období 1990 - 1996. Postupně byla zpracována řada návrhů dalšího postupu. Nakonec byla od 1. 4. 1996 vyhlášena likvidace chemické těžby uranu ve Stráži pod Ralskem jako výsledek ekologicko-ekonomického posouzení možných variant.

Sanace horninového prostředí je časově a finančně nejnáročnější likvidační činností. Bude prováděna $\mathrm{v}$ několika krocích po dobu třiceti let.

Prvním krokem sanace chemické těžby je vytvoření hydraulické podbilance $\mathrm{v}$ cenomanské zvodni $\mathrm{v}$ oblasti vyluhovacích polí tak, aby bylo zabráněno dalšímu šíření kontaminace do doposud nezasaženého horninového prostředí. Od roku 1996 je k sanačnímu zpracování roztoků provozována technologie odpařování, která navození podbilance umožňuje vyváděním cca $5,5 \mathrm{~m} 3 / \mathrm{min}$ destilované vody. Po vybudování navazujících zpracovatelských technologií 
budou postupně cenomanské roztoky zbaveny rozpuštěných solí. Vyčištěná voda bude vypouštěna do vodotečí či využita při sanaci a získané soli budou přepracovány na průmyslově využitelné produkty či materiály. Konečná úroveň snížení kontaminace $\mathrm{v}$ turonské a cenomanské zvodni není v současné době stanovena a bude v průběhu sanace upřesňována. Sanace horninového prostředí bude ukončena imobilizací zbytkové kontaminace

Po ukončení sanace horninového prostředí budou postupně likvidovány všechny vrty vyjma těch, které se využívají $\mathrm{k}$ monitorování po ukončení celkové likvidace.

Povrch vyluhovacích polí byl rozčleněn podle způsobu jeho rekultivace. Území stávající chemické těžby bude $\mathrm{v}$ budoucnu sloužit pro rekreační účely se zohledněním lesního hospodaření a zájmů ochrany přírody.

Likvidace chemické těžby je komplexní problém, ve svých souvislostech ojedinělý i v mezinárodním měřítku. Ukončení likvidace se předpokládá přibližně v roce 2040 a náklady se pohybují v desítkách miliard Kč.

\section{Sum mary}

\section{URANIUM INDUSTRY AND RALSKO}

The aim of decontamination measures is a complex liquidation of mining works and surface equipments in the whole region, with the exception of surface buildings and equipments suitable for further usage, decontamination and recultivation of dumps and slime pits and their progressive incorporation into the landscape. The aim of liquidation activities and decontamination measures with regard to obliteration of impacts of chemical extraction of uranium is to bring the rock environment into a state which would prevent a deterioration of the fresh water contained in the North-Bohemian Cretaceous, and consequently to liquidate the drills and the non-usable equipment which were used for mining, and finally to recultivate the surface of lixiviation fields based on plans for the future usage of the territory.

The surface of lixiviation fields was divided according to the way of its recultivation. The territory of the present chemical extraction will serve in future for recreation purposes with a particular stress put on forestry and nature protection.

The liquidation of chemical extraction is a complex problem, in its connections unique even at the international scale. The completion of liquidation should be achieved in approximately 2040 and its costs will reach tens of milliards Kč.

Fig. 1 - State firm DIAMO, Stráž pod Ralskem - mining and processing plants and seat of individual plants. 1 - deep mining, 2 - chemical extraction, 3 - radiometric processing plant, 4 - chemical processing plant, 5 - individual plant. Stráž pod Ralskem, Rožná = present producers of uranium.

Fig. 2 - Position of the Stráž block within the Czech Republic. 1 - Stráž block, 2 - Bohemian Cretaceous Basin.

Fig. 3 - Uranium ores deposits in the region of the Stráž block. 1 - Stráž deposit, 2 - Křížany deposit, 3 - Břevniště deposit, 4 - Hamr deposit, 5 - Mimoň deposit, 6 - Hvězdov deposit, 7 - Holičky deposit, 8 - Osečná-Kotel deposit. a - Tlustec block, b - Stráž block, c - Stráž fault, d - Lužická disturbance, e - the belt of the Čertova zed’ wall.

(Pracoviště autora: DIAMO, s. p. Stráž pod Ralskem, 47127 Stráž pod Ralskem.)

Do redakce došlo 21. 4. 1998

Lektorovali Václav Poštolka a Zbyněk Ryšlavý 